Ethiopian Journal of Environmental Studies \& Management 9(6): 780 - 792, 2016.

ISSN:1998-0507

doi: http://dx.doi.org/10.4314/ejesm.v9i6.10

Submitted: August 22, 2016

Accepted: November 10, 2016

\title{
SPATIO-TEMPORAL ANALYSIS OF LANDUSE DYNAMICS IN UPPER OPA CATCHMENT, SOUTHWEST NIGERIA
}

\author{
${ }^{*}$ IBITOYE, M.O., ${ }^{1}$ ABOYEJI, 0.S. ${ }^{2}$ AND ADEKEMI, S.O.A. ${ }^{2}$ \\ ${ }^{1}$ Department of Remote Sensing and Geoscience Information System, Federal University \\ of Technology, Akure, Nigeria \\ ${ }^{2}$ Regional Centre for Training in Aerospace Surveys (RECTAS), Ile-Ife, Nigeria
}

\begin{abstract}
This study explored the use of geospatial techniques to assess land use change within upper Opa catchment area in Ile-Ife, Osun State, Nigeria for a period of 28 years between 1986 and 2014. To accomplish this, Landsat TM 1986, ETM 2002 and OLI 2014 were acquired from the USGS Earth Explorer in Global Land Cover Facility (GLCF) web site and subjected to supervised classification using the Anderson classification Scheme. Six land use/landcover classes were identified: Built-up, Bareland, Riparian, Forest Vegetation, Rock Outcrop and Water body using ENVI 5.1 Software. A change detection analysis of LULC was carried out to provide the necessary understanding of changes over the period and prediction for expected change in future was carried out. Result showed remarkable changes in all the land uses. For instance, Built-up increased from $7.01 \mathrm{~km}^{2}(6.4 \%)$ in 1986 to $11.92 \mathrm{~km}^{2}$ (10.8\%) and $20.86 \mathrm{~km}^{2}(18.8 \%)$ in 2002 and 2014, respectively while vegetation reduced from $61.72 \mathrm{~km}^{2}(61.30 \%)$ in 1986 to $55.41 \mathrm{~km}^{2}(50.2 \%)$ in 2014 . The study further confirmed that if the current rate of reduction in the vegetation cover is allowed to continue unabated, there may be no vegetation again in the area in the next 30 years, thus, jeopardizing the need of the future generation and causing greater harm to the environment. In view of the above, efforts should be made to control land use activities within upper Opa catchment by enforcing the "Green Policy" of the Environment Act of the Federal Government of Nigeria which will check the indiscriminate land uses particular the encroachment of other uses into vegetation land.
\end{abstract}

Key words: Opa Catchment, LULC, Anthropogenic activities, Southwestern Nigeria

\section{Introduction}

Many developing countries of the world today could be said to be suffering from serious environmental degradation resulting from human and natural causes. An important human factor is rapid growth in population which has brought about gross entry into areas which was previously occupied by natural forests. People are now concern about the raising problem as a result of deforestation, which is the temporary or permanent clearing of forest either for agriculture purpose or any other purposes. Since 
Spatio-Temporal Analysis of Landuse Dynamics................IBITOYE et al.

prehistoric times, forest serves various purposes and will continue to do so as long as life continues on this planet (Abbiw, 1990). The forest houses and protects game, stabilizes the environment, prevents soil erosion and serves as a source of medicinal plants for curing diseases. Forests also provide the greatest diversity of plant life, yet they continue to be felled through logging and faming activities and at times through burning and they are seldom replaced. In many parts of Nigeria, the forestry sector contributes significantly to the internally generated revenue (IGR) in some state (Akindele, 2001). Ajayi (2001) opined that between 1996 and 2001, this sector generated N608, 460,455.78 from the sales of timber alone.

Nigeria is about $923,770 \mathrm{~km}^{2}$, and forests accounted for only $9.61 \%$, while grassland $48.53 \%$, fresh and inland wetlands $1.05 \%$, tree crop plantations $0.3 \%$ and farmlands $20.33 \%$ (Omiyale, 2001). He observed that an estimate of $43.48 \%$ of the total forest ecosystem in Nigeria has been destroyed by human activities between the period of 1980 and 1990. Popoola and Akande (2001) argued that the annual rate at which forest is been destroyed for farming and other anthropogenic activities averagely is about $3.5 \%$ and forest area losses from 14.9 million to 10.1 million hectares annually. In 2001, about $5.34 \%$ of the total land area of Nigeria was under forest as against the international requirement where $25 \%$ of the total land area of each country was mandated to be under forest (Popoola and Akande, 2001).

Land expansion and modernization has become a major problem in Nigeria especially, in the tropical forest region such as Osun state. It is a problem because of the present experience in climate change, biodiversity loss and pollution. Knowing that forest communities have a vital role to play in maintaining balanced eco-system of the world, still pressures from the exploding population and the subsequent growing needs of industries, food, fuel wood, fodder, timber activities etc., depletion and degradation of forests and subsequently severe negative changes in ecosystem (Andreas and Hugh, 2009; Omiyale, 2001). Omiyale (2001) was of the opinion that if 6.1 million hectares of tropical forests are destroyed annually in 170 years, the total tropic forest would have completely wiped out.

Uncontrolled human (anthropogenic) activities has led to significant modification of the natural biodiversity in Southwestern Nigeria as in the case of upper Opa catchment, which has led to abrupt change in land use and land type without adequate consideration for sustainable developments. Monitoring and assessing the effect of anthropogenic activities especially those that has to do with land use changes is helpful in order to catalogue the diverse effects of this land use change on forested areas and other human endeavours. Hence, information on land use and possibilities for their optimal use is essential for the selection, planning and implementation of land use schemes to meet the increasing demands for basic human needs and welfare without jeopardizing the need of future generation.

Several studies have been carried out on LULC in various parts of the world (Adeoye, 2012; Aduah and Aabeyir, 2012; Fernandez and Dhorde, 2014; Oyinloye and Oloukoi, 2012; Shiferaw, 
2011; Tran et al., 2015; Turan et al., 2010). As regards the study area, it has been a focus for many researches because of its location within a university (Obafemi Awolowo University, Ile Ife) environment. Apart from the work of Adediji and Jeje (2004) who worked on land use and sediment delivery ratio in Opa basin and Adediji (2005) on reservoir sedimentation on Opa catchment, there is no known research record on land use land cover dynamics in Opa Catchment. Thus, this study aims in providing the information (on LULC) using the advancement in space technology particularly in Remote sensing and GIS applications. The result of the study is hoped to provide relevant information for effective monitoring, planning and formulation of policies that would support the conservation of the environment and nature in the area.

\section{Study Area}

The study area which is approximately $110 \mathrm{~km}^{2}$ in size extends from part of Ile Ife, capital of Ife Central Local Government including Obafemi Awolowo University campus in Ile-Ife, to Osu town in Atakumosa West Local Government Area (Figure 1). The study area lies within Latitudes $7^{\circ} 27^{\prime} \mathrm{N}$ and $7^{\circ} 35^{\prime} \mathrm{N}$ and Longitudes $4^{\circ} 31^{\prime} \mathrm{E}$ and $4^{\circ} 39^{\prime} \mathrm{E}$ and falls under Koppen's Af humid tropical rainforest climates. The daily minimum temperature is $25^{\circ} \mathrm{C}$ while the mean maximum is $33^{\circ} \mathrm{C}$ (Adejuwon and Jeje, 1975). The mean annual rainfall is about $1400 \mathrm{~mm}$, with the rainy season between April and October. The rainy season is marked by two maxima, in June/July and September/October. These two periods are separated by a short dry spell in August. The area is characterized by natural vegetation of the tropical rainforest of multiple canopies and lianas (Adediji, 2005). However, the persistent removal of the natural vegetation for cultivation of arable crops such as yam, cocoyam, plantain, cassava, maize etc. and cash crops such as cocoa, kolanut etc. in a mixed faming pattern coupled with logging activities has led to the destruction of the original vegetation.

As evident from the above activities, the people are predominantly Yoruba farmers of Ile Ife with their farmsteads, camps and hamlets such as Mokuro, Amuta, Poju, Fadugbo, Itamerin and Alakowe located at different areas within the catchment. 


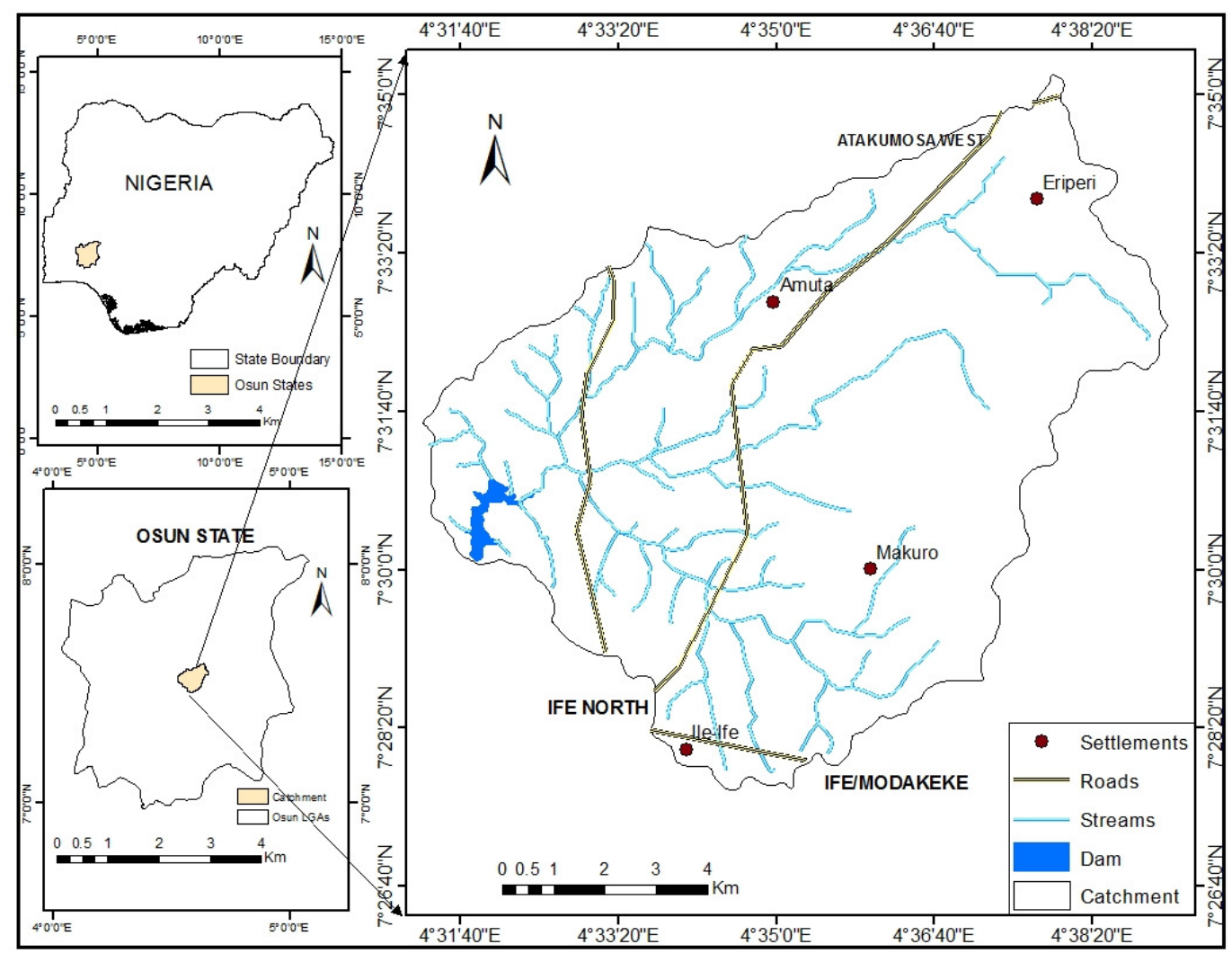

Figure: The Study area

\section{Materials and Methods}

The data used for the study consists of Landsat satellite images, ancillary data such as administrative and topographic maps, and GPS data collected from fieldwork. Landsat image data are popular data sources for documenting spatio-temporal changes in land cover and use due to their long history, reliability, and availability and medium resolution (Lui and Coomes, 2015; Townsend et al., 2009). Multi-date Landsat satellite image of 1986, 2002 and 2014 captured by the satellite during the dry season (months of November to March) were used for the study. Dry season image data were adopted in other to avoid seasonal variations of topographic details, particularly vegetation cover, and the possibility of obtaining cloud-free images. The image data were used to generate the land use/cover for the study period. In addition, ancillary data consisting of administrative and topographic maps were used to derive the administrative boundaries and topographic information within and around the study area.

\section{Image Processing and Classification}

The Landsat satellite images data which were delivered with UTM Zone $31 \mathrm{~N}$ projection using the WGS 1984 Datum, were pre-processed to correct for radiometric and geometric errors. The corrections were conducted using calibration tool and Fast Line-of-sight Atmospheric Analysis of Hypercubes (FLAASH) algorithm in ENVI 5.1 software environment (Hester et al., 2008; Lui and Coomes, 2015). The 
algorithm converts the original digital number (DN) data in the raw Landsat image scenes to top-of-atmosphere reflectance values. Supervised classification procedure using Maximum likelihood classification algorithm was applied to each of the resulting reflectance images to produce the land use/land cover classes.

Regions of Interest (ROIs) of six land-cover classes of interest were identified using visual interpretation and spectral assessments of the Landsat image and corroborated with highresolution Google Earth ${ }^{\mathrm{TM}}$ imagery of the study area. This process is commonly referred to as training sites because the spectral characteristics of those known areas were used to train the classification algorithm for eventual land use/cover mapping of the images. Based on Anderson I-level classification scheme, six classes were identified on each image. The classes are Vegetation (V); built-up (BU); Bare land (BL); water body (WB); Rock outcrop (RO) and riparian forest (RF). Maximum Likelihood algorithm, an effective and commonly used classifier (Churches et al., 2014; Lui and Coomes, 2015), was used for the classification. The algorithm assumes a normal distribution of reflectance values for each user-defined class within each spectral band of the original satellite image, and assigns each pixel to a specific class based on the probability of it belonging to that class. ENVI's default refinement parameters setting smoothing kernel size to 3 (i.e., $3 \times 3$ pixels) and aggregate minimum size to 9 pixels were employed to remove "salt-and-pepper" effects. The classification procedure resulted in a map of landuse/land cover pattern of the study area for the various epochs under consideration.

Analysis of Spatio-temporal Changes in the Land Use/Land Cover

Changes in land cover types from 1986 - 2002 and 2002 - 2014 were determined by identifying differences between the classified maps of 1986, 2002, and 2014 using Intensity analysis (Aldwaik and Pontius, 2012). Aldwaik and Pontius (2012) defined Intensity Analysis as the quantitative framework to account for differences among categories as summarized by a square transition matrix for which the row categories are identical to the column categories

The areas covered at a given land cover type for the different times were compared and the nature of changes either positive or negative in each land cover type in 1986, 2002 and 2014 were obtained. To provide a range of estimates of LULC since 1986, two independently developed land cover maps were used (Ishaq et al., 2012). The most conservative LULC changes as a result of anthropogenic activities estimates were made using the intersection of both maps, i.e., where both agreed on a given land cover type classification.

\section{Prediction of Land Use and Cover Changes}

Continuity of spatial and temporal changes of LULC in Opa Catchment from 1986 to 2014 was analysed using Markov chain model. Markov chain analysis is appropriate for forecasting trend of land use system based on transition probability matrix, which records the probability that each land cover category will change to every other category (Bottomley, 2000). The procedure determines exactly how much land would be expected to transit from 
the later date to the predicted date based on a projection of the transition potentials into the future. An important assumption of the procedure is that LULC change is regarded as a stochastic process, and different categories are as the states of a chain (Weng, 2002). Markov chain models have been widely used to predict land use and land cover changes (Gong et al., 2015; Ma et al., 2012; Takada et al., 2010; Yang et al., 2011; Zhang et al., 2011). For this work, MARKOV module of IDRISI 17.0 (Selva Edition) software was used. The MARKOV module was used to analyse a pair of land cover images and outputs a transition probability matrix, a transition areas matrix, and a set of conditional probability images.

\section{Result and Discussion}

\section{Temporal Pattern of Land Use/Land} Cover between 1986 and 2014

Six land use classes were identified in the study area as shown in Table 1 . Some land uses were on continuous increase while others were steadily decreasing. For instance, in a space of 28 years (1986 -2014), built up area increased from 7.1 $\mathrm{km}^{2}$, that is $6.4 \%$ of the total catchment area in 1987 to $11.9 \mathrm{~km}^{2}(10.8 \%)$ and $20.7 \mathrm{~km}^{2}(18.9 \%)$ in 2002 and 2014, respectively with an overall increase of $13.6 \mathrm{~km}^{2}$ which translated to $195 \%$ increase. It was observed that between 1986 and 2002 (16 years period), the increase was $4.85 \mathrm{~km}^{2}$ translating to an average of $0.30 \mathrm{~km}^{2} / \mathrm{yr}$ and between 2002 and 2014, a period of 12 years, the increase was $8.95 \mathrm{~km}^{2}$ averaging $0.74 \mathrm{~km}^{2} / \mathrm{yr}$. The record further revealed that increase of $8.95 \mathrm{~km}^{2}$ recorded in the space of 12 years (2002-2014) in the built up land use, was almost double $4.85 \mathrm{~km}^{2}$ recorded in a 16 years period between 1986 and 2002. The reason for this astronomical increase in the built up area could be as a result of the economic policy put in place by both the Federal and State Government that brought about improvement in both social and economic activities during this period. This has in turn translated to improvement in living standard of the people particular the civil service workers, traders and artisans and one of the resultant effects is the demand for residential buildings. As a matter of fact the built up area encroached into virtually all the identified land uses in the study area with bare land and vegetation suffered great loss. The dynamism observed in this study also conform with the result of land use land cover dynamics carried out by Adeoye (2012) in the city of Lokoja, Nigeria, Ejaro and Abdullahi (2013) in Suleja LGA, Nigeria, Aduah and Aabeyir (2012) in Wa Municipal in Ghana and Areendran et al. (2013) in Singrauli district, Indian.

Bareland occupied $29.05 \mathrm{~km}^{2}$, about $26.3 \%$ which was the second largest land use type, after the vegetation land use, in 1986 in the study area. This position was maintained in 2002 with $39.20 \mathrm{~km}^{2}$ $(35.5 \%)$ of the total land cover but with a loss of about $9.36 \mathrm{~km}^{2}$ in 2014 . Incidentally, it was the same period $(2002-2004)$ the built up gain more area of land, thus confirming a positive correlation between the two land uses. A cursory look at the spatial land use maps (see Figure 6 and 7) of the study area for 2002 and 2014, will confirm this land use dynamism.

The riparian forest land use in the study area also experienced very slight changes either as gain or loss during the 
period of study (1986-2014). In 1986 it has a total of $4.64 \mathrm{~km}^{2}(4.2 \%)$ with a slit gain of $0.84 \mathrm{~km}^{2}$ to make a total of $5.48 \mathrm{~km}^{2}$ in 2002 . By 2014, it decreased to $3.39 \mathrm{~km}^{2}$. The decrease might be as a result of encroachment from other land uses majorly from built up class.

As a common phenomenon in land use land cover dynamics studies, vegetation land use class is always at the mercy of other land uses such as bareland as a result of farming and logging activities and urbanization process. In the study area, the vegetation land use lost tremendously to other land uses such as built up and bareland. In 1986, vegetation land use had a total area of $67.72 \mathrm{~km}^{2}$ translating to $61.30 \%$ of the total catchment area. It means that as at 1986 , more than half of the upper Opa Catchment Area was covered with vegetation. By 2002 it reduced to $52.59 \mathrm{~km}^{2}$ which was about $47.63 \%$ of the total area of the catchment similar to the observation of Showqi and Bhot (2014) on land use land cover dynamics study in the Romshi Watershed, India. Surprisingly, there was a gain of about $2.81 \mathrm{~km}^{2}$ from other land uses probably from bareland between 2002 and 2014 to have a total square kilometer of 55.41 in the study area. The observed pattern could be as a result of the improvement in the standard of living amongst the citizen which resulted to the use of gas or kerosene as against firewood for cooking and less opening of more land for farming activity. This might have likely gave rise to regeneration of the vegetation, hence the increase observed in the vegetation land use.

Pond, stream and wetland were classified as water body in the study. There was a steady decrease in the water body from $0.72 \mathrm{~km}^{2}$ in 1986 to $0.46 \mathrm{~km}^{2}$ in 2002 and $0.40 \mathrm{~km}^{2}$ in 2014. Between 1986 and 2002, about $0.26 \mathrm{~km}^{2}$ was encroached upon by other use such as residential building (built up land use) particularly along the water body situated within the developed areas of the study area.

Rock outcrop occupied a reasonable portion of the study area. For instance, in 1986, rock outcrop was $1.25 \mathrm{~km}^{2}$, translating to $1.13 \%$ of the total land cover. This use was by 2002 and 2003 reduced to $0.77 \mathrm{~km} 2$ and $0.56 \mathrm{~km} 2$ respectively. The steady loss of this land use type might be as a result of increase quarry activities and demand for land for residential purpose particularly in the built up area.

Table 1: Land use land cover on temporal basis between 1986 and 2014

\begin{tabular}{llllllll}
\hline $\begin{array}{l}\text { Land use/ } \\
\text { Land cover }\end{array}$ & \multicolumn{2}{l}{ Area $\left(\mathrm{km}^{2}\right) / \%$} & & \multicolumn{2}{c}{ Magnitude $\left(\mathrm{Km}^{2}\right)$} & \multicolumn{2}{l}{$\begin{array}{l}\text { Rate per annum } \\
\left(\mathrm{km}^{2}\right)\end{array}$} \\
\hline & 1986 & 2002 & 2014 & $86-02$ & $02-14$ & $86-02$ & $02-14$ \\
\cline { 2 - 7 } $\begin{array}{l}\text { Built-up } \\
\text { Bareland }\end{array}$ & $7.07(6.4)$ & $11.92(10.8)$ & $20.86(18.9)$ & 4.85 & 8.94 & 0.30 & 0.75 \\
Riparian & $4.05(26.3)$ & $39.20(35.5)$ & $29.84(27.0)$ & 10.15 & -9.36 & 0.63 & -0.78 \\
Forest & $4.64(4.2)$ & $5.48(5.0)$ & $3.39(3.1)$ & 0.84 & -2.09 & 0.05 & -0.17 \\
Vegetation & $67.72(61.3)$ & $52.60(47.6)$ & $55.41(50.2)$ & -15.12 & 2.81 & -0.95 & 0.23 \\
Water body & $0.73(0.7)$ & $0.46(0.4)$ & $0.40(0.4)$ & -0.27 & -0.06 & -0.02 & -0.01 \\
Rock outcrop & $1.25(1.1)$ & $0.77(0.7)$ & $0.56(0.5)$ & -0.48 & -0.21 & -0.03 & -0.02 \\
\hline Total & 110.46 & 110.43 & 110.47 & & & &
\end{tabular}




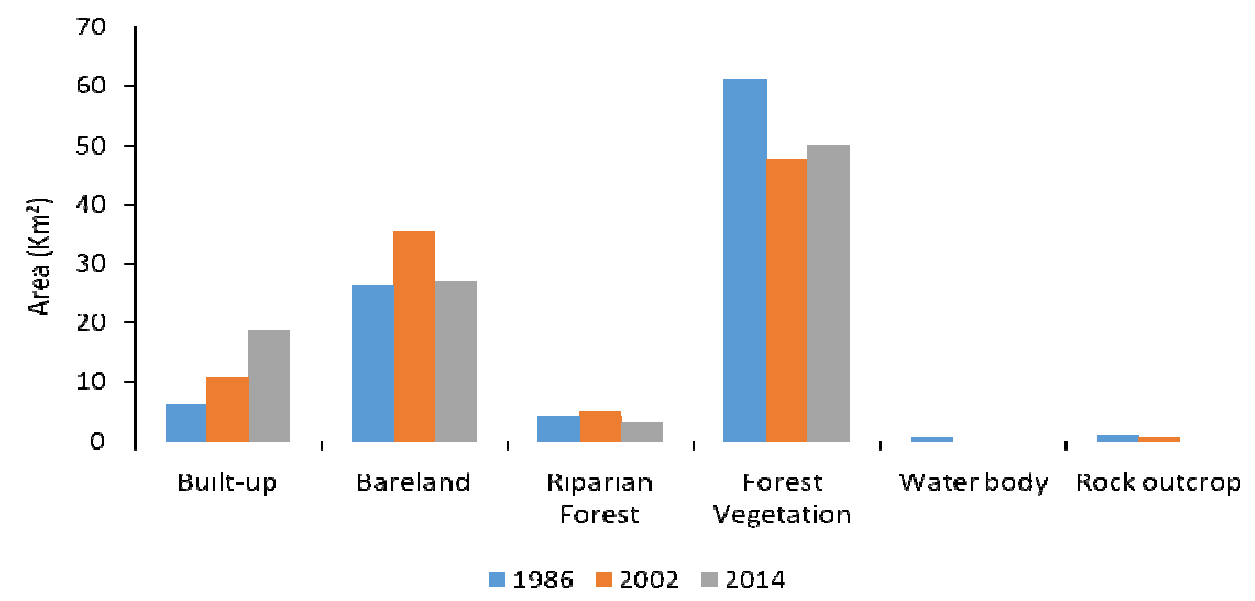

Figure 2: Relative land cover changes in the study area (1986-2014)

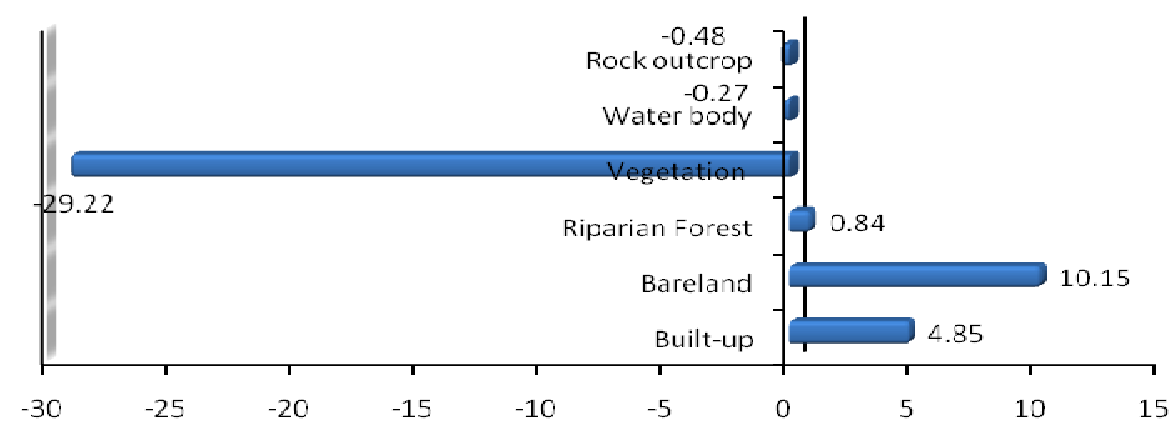

Figure 3: Gains and losses of LULC classes between 1986 and 2002

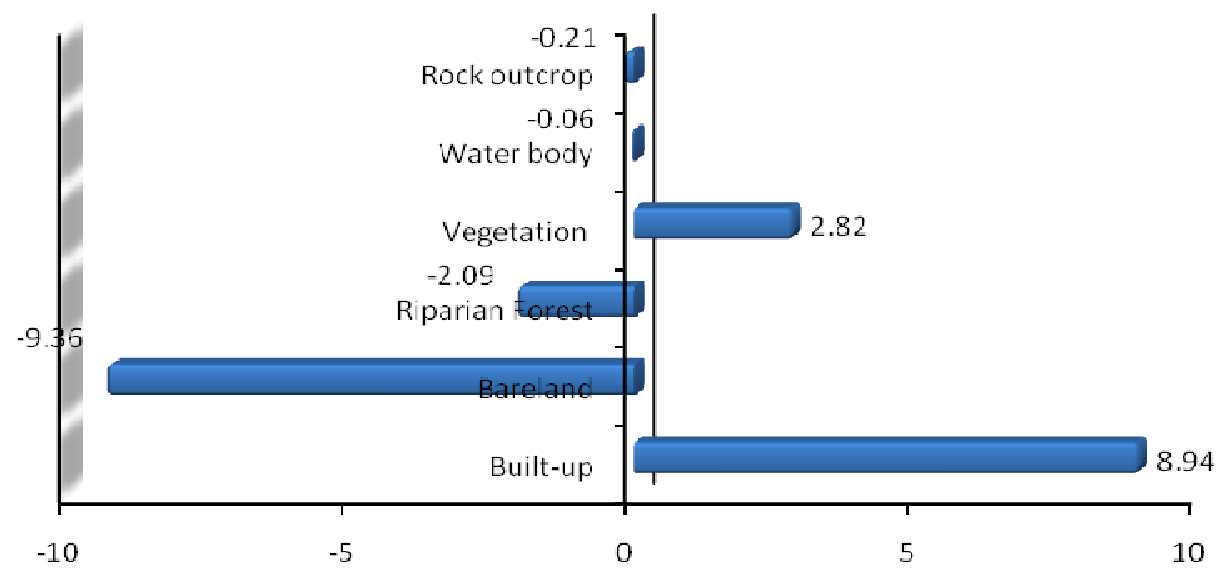

Figure 4: Gains and losses of LULC classes between 2002 and 2014

Spatial Pattern of Land Use/Land Cover between 1986 and 2014

As evident from the land use maps (Figures 5, 6 and 7) for the various years under consideration (i.e.1986-2014), six land use types were classified and all the uses experienced one form of change or the other. Apart from water body that 
followed a pattern, all other uses spread spatially all over the entire area. For instance in 1986, the areal extent of the built up area was limited to the south western part of the catchment and was surrounded by bareland while the greater parts of the catchment was vegetation (Figure 5). By 2002, the built up land use had taken over areas identified in 1986 as bareland and new bareland was created through anthropogenic activities such as farming, bush burning, logging into land use area formerly regarded as vegetation in 1986 (Figures 2 and 6). The bareland spread predominantly to the eastern parts of the catchment. In 2014 the vegetation land use was more or less reduced to half of what it was in 1986 (Figure 3 and 7). This was as result of increase in population and consequently, increase in the needs for food, shelter and other commercial activities. It is therefore a common knowledge that if this pattern of land use dynamism continues unabated, in 30 years time, there will be no vegetation in the study area. Thus, jeopardizing the need of the future generation and causing greater harm to the environment. Forest removal has been observed as one of the key factors enhancing global warming that threatens the environment. Plants make use of carbon dioxide (a greenhouse gas) during photosynthesis thereby reducing its concentration in the atmosphere. The environmental implication of this development is that the catchment will be contributing negatively to the climate change problem in Nigeria. Other land uses such as riparian forest, rock outcrop and water body in the study area if not properly monitored and checked may lead to more devastating environmental problems such as erosion, flooding, loss of soil fertility and impoundment of Opa water reservoir (Adediji, 2005).

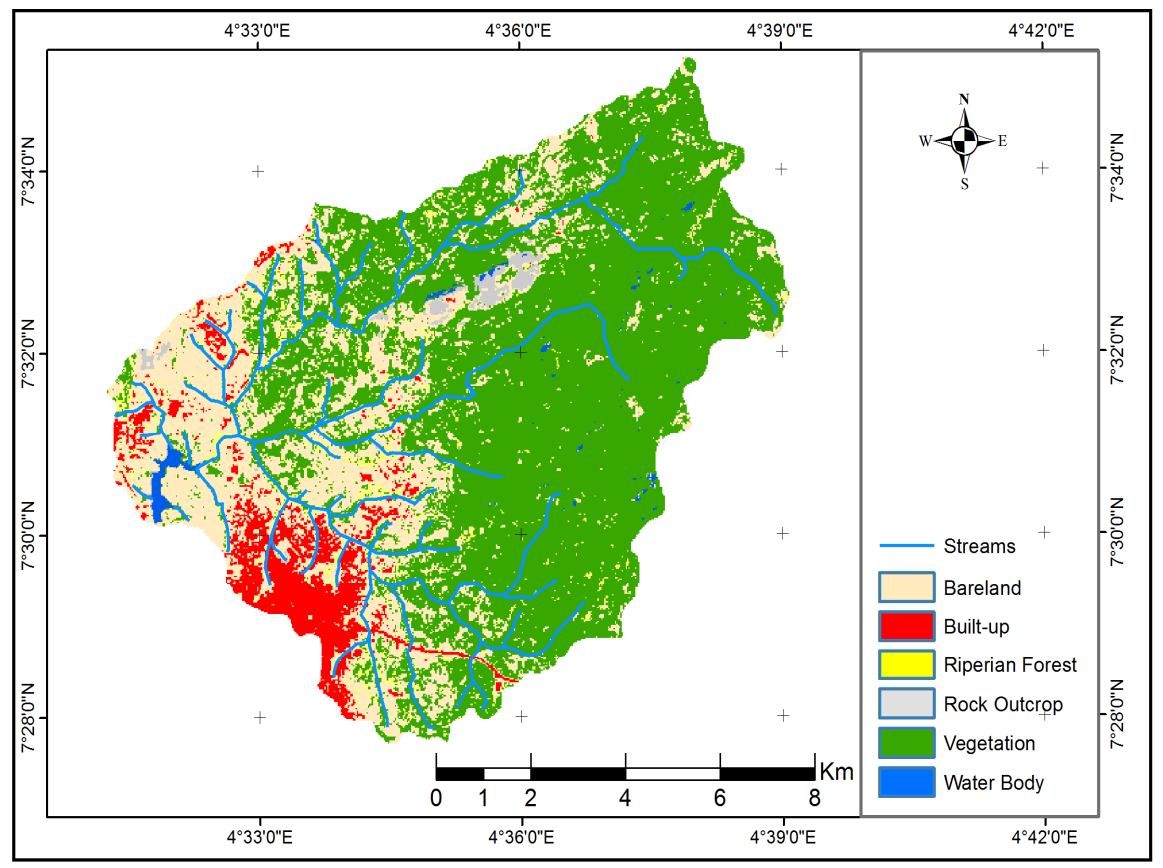

Figure 5: Spatial pattern of land use and land cover in 1986 


\section{Spatio-Temporal Analysis of Landuse Dynamics................IBITOYE et al.}

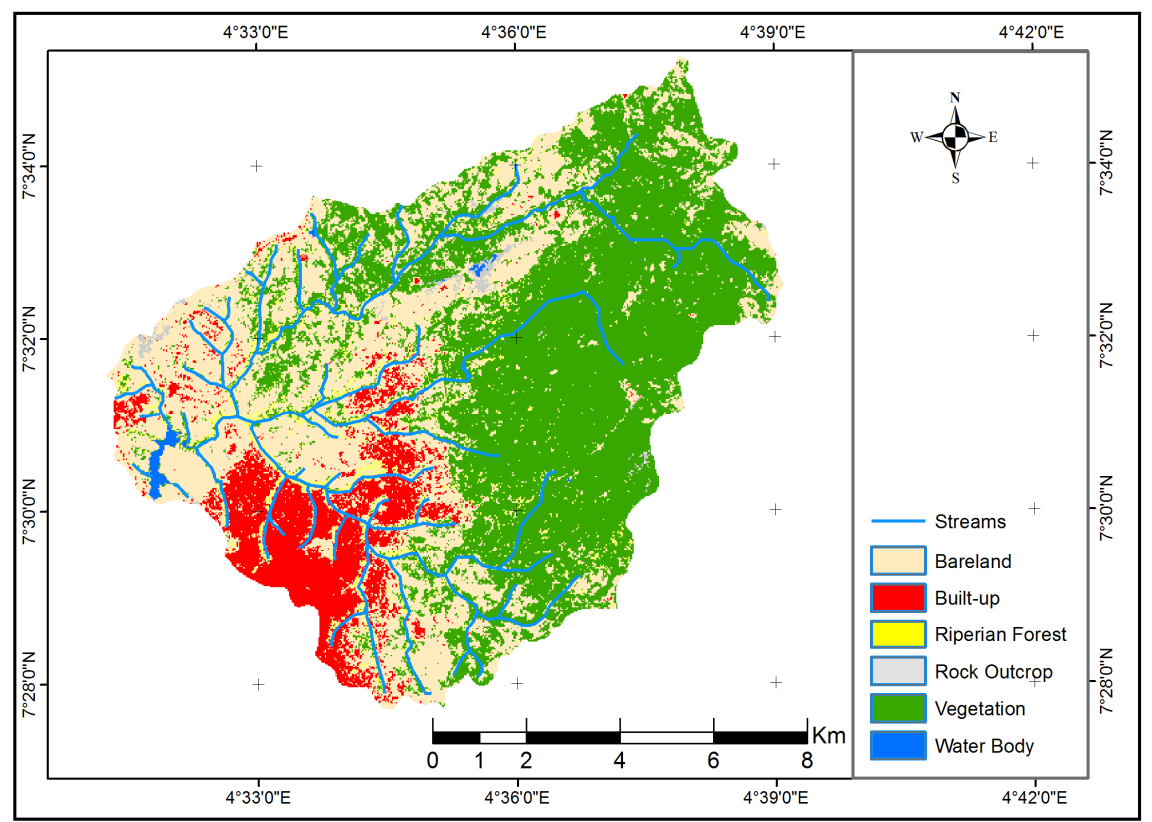

Figure 6: Spatial pattern of land use and land cover in 2002

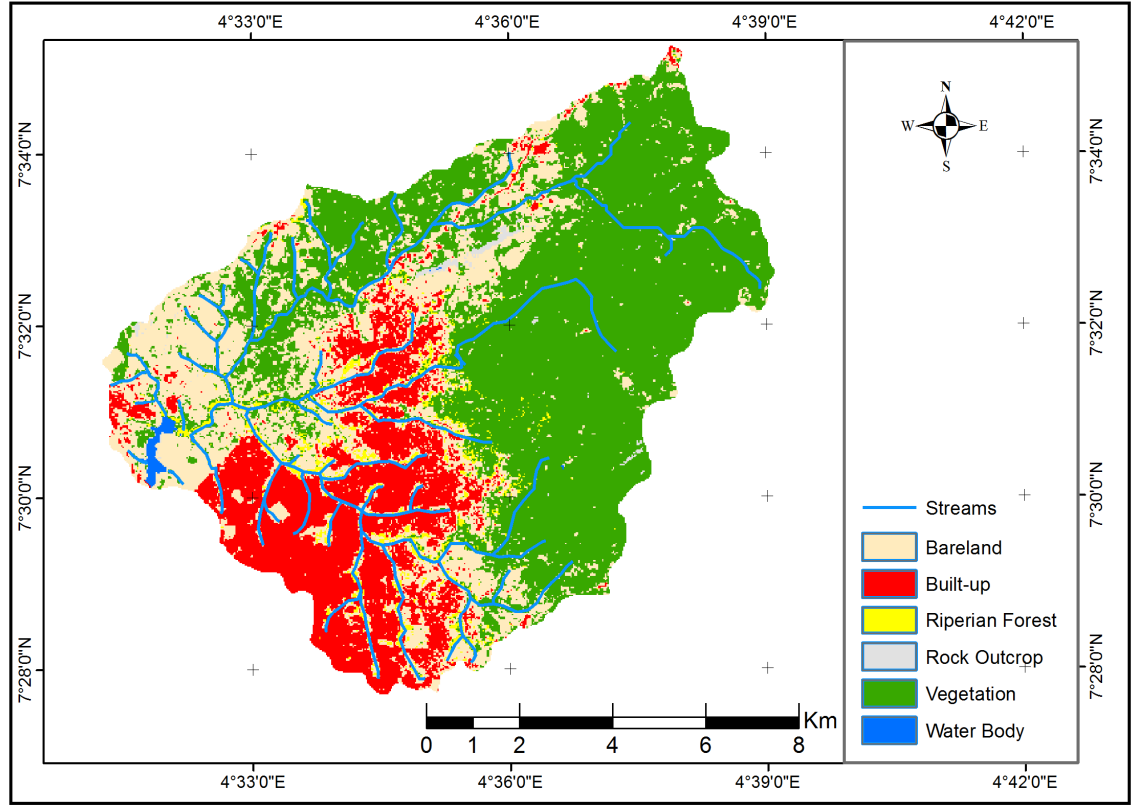

Figure 7: Spatial pattern of land use and land cover in 2014

\section{Conclusion}

This study has generated a synthetic of knowledge on land use land cover in the study area between 1986 and 2014 using remote sensing and GIS technologies. Six prominent land use types consisting of bareland, built up, riparian forest, rock outcrop, vegetation 
and water body were identified. The result clearly shows that land use land cover changes were significant during the period under consideration (1986 to 2014). The most dynamic of these land uses were bareland and built up areas with urbanization process largely responsible for the significant change and modification. The study revealed an encroachment of about $13.16 \mathrm{~km}^{2}$ from built up into surrounding bareland and vegetation land uses. It was also noted that the negative change recorded in the vegetation land use cover for the period (28 years) was almost by the same proportion at which the built up land cover increased in 2014.

In general, the activities within the catchment were driven by rapid growth of population and urbanization. The factor gave rise to demand for the basic essential things such as food, shelters, thus leading to clearing of more land for farming, logging for economic gain and buildings to accommodate population. The result of this phenomenon brings into mind its environmental consequences and hence, the call for control and preservation of the environment. This is by ensuring that measures that will guarantee sustainable use of the catchment are put in place.

\section{References}

Abbiw, D.K. (1990). Useful plants of Ghana. Intermediate Technology Publications \& The Royal Botanic Gardens, Kew, London.

Adediji, A. (2005). Reservoir sedimentation: the case or the Opa Reservoir catchment, Southwestern Nigeria. South African Geographical Journal, 89: 123-128.
Adediji, A., Jeje, L.K. (2004). Land use and Sediment delivery ration in the Opa Basin, southwestern Nigeria. Tropical Agriculture, 81: 133-140.

Adejuwon, J.O., Jeje, L.K. (1975). Land element of the environmental system of Ife area, in: Ojo, A. (Ed.), Environmental Resources Bases Project No. 2, Department of Geology, University of Ife, Ile-Ife.

Adeoye, N.O. (2012). Spatio-temporal analysis of land use/land cover change of Lokoja- A Confluence town. Journal of Geography and Geology, 4: 40-51.

Aduah, M.S. and Aabeyir, R. (2012). Land cover Dynamics in Wa Municipality Upper Water Region of Ghana. Research Journal of Environmental and Earth Sciences, 4: 658-664.

Ajayi, B. (2001). Wood wastes management in forest industries. Journal of Tropical Forest Resources, 17: 91-102.

Akindele, S.O. (2001). Forest Assessment for Sustainable Development. Journal of Tropical Forest Resources, 17: 35-40.

Aldwaik, S.Z. and Pontius, R.G. (2012). Intensity analysis to unify measurements of size and stationary of land changes by interval, category, and transition. Landscape and Urban Planning, 106: 103-114.

Andreas, B.B. and Hugh, D.E. (2009). Monitoring 25 years of land cover change dynamics in Africa: A sample based remote sensing approach. Journal of Applied Geography, 29: 501-512.

Areendran, G., Rao, P., Raj, K., Mazumdar, S. and Puri, K. (2013). Land use/land cover change 
dynamics analysis in mining areas of Singrauli District in Madhya Pradesh, Indian. Tropical Ecology, 54: 239-250.

Bottomley, B.R. (2000). Mapping Rural Land Use and Land Cover Change in Carroll County, Arkansas Utilizing Multi-temporal Landsat Thematic Mapper Satellite Imagery 1984-1999. University of Arkansas, Fayetteville.

Churches, C.E., Wampler, P.J., Sun, W. and Smith, A.J. (2014). Evaluation of forest cover estimates for Haiti using supervised classification of Landsat data. International Journal of Applied Earth Observation Geoinformation, 30: 203-216.

Ejaro, S. and Abdullahi, U. (2013). Spatiotemporal analyses of land use land cover changes in Suleja Local Government Area, Niger State. Journal of Environment and Earth Science, 3: 72-83.

Fernandez, R.B. and Dhorde, A.A. (2014). Assessment of spatiotemporal variations in land use land cover over Pimipri Chinch Wad Municipal Corporation using remote Sensing data. Journal of Geomatics and Geosciences, 4: 609-618.

Gong, W., Yuan, L., Fan, W. and Stott, P. (2015). Analysis and simulation of land use pattern in Harbin prefecture using cellular based on trajectories and cellular automataMarkov modelling. International Journal of Applied Earth Observation and Geoinformation, 34: 207-216.

Hester, D.B., Cakir, H.I., Nelson, S.A.C., Khorram, S. (2008). Per-pixel classification of high spatial resolution satellite imagery for urban land-cover mapping. Photogrammetric Engineering and Remote Sensing, 74: 463-471.

Ishaq, S.E., Agada, P.O. and Rufus, S. (2012). Spatial and Temporal Variation in Water Quality of River Benue, Nigeria. Journal of Environmental Protection, 3: 915921.

Lui, G.V., Coomes, D.A. (2015). A Comparison of Novel Optical Remote Sensing-Based Technologies for ForestCover/Change Monitoring. Remote Sensing, 7: 2781-2807.

Ma, C., Zhang, G.Y., Zhang, X.C., Zhao, Y.J. and Li, H.Y. (2012). Application of Markov model in wetland change dynamics in Tianjin Coastal Area, China. Procedia Environmental Sciences, 13: 252 262.

Omiyale, O. (2001). Impact of encroachment on sustainable forest development. Journal of Tropical Forest Resources, 17: 23-33.

Oyinloye, R.O. and Oloukoi, J. (2012). Spatio-Temporal assessment and Mapping of the Land use land cover dynamics in the central forest belt of southwestern Nigeria. Research Journal of Environmental and Earth Sciences, 4: 720-730.

Popoola, L. and Akande, J.A. (2001). An integrated approach to forestry sector impact assessment in Nigeria. Journal of Tropical Forest Resources, 17: 42-56.

Shiferaw, A. (2011). Evaluating the land use and land cover dynamics in Borena Woreda of South Wollo Highlands, Ethiopia. Journal of 
Sustainable Development in Africa, 13: 87-107.

Showqi, I. and Bhot, G.A. (2014). Evaluating spatio-temporal dynamics of land use land cover in Romshi watershed of Jhelum Basin, Jammu and Kashmir. India World Applied Sciences Journal, 32: 848852.

Takada, T., Miyamoto, A. and Hasegawa, S.F. (2010). Derivation of a yearly transition probability matrix for land-use dynamics and its applications. Landscape Ecology, 25: 561-572.

Townsend, P.A., Lookingbill, T.R., Kingdon, C.C., Gardner, R.H. (2009). Spatial pattern analysis for monitoring protected areas. Remote Sensing of Environment, 113: 14101420.

Tran, H., Tran, T. and Kervyn, M. (2015). Dynamics of Land Cover/Land Use Changes in the Mekong Delta, 1973-2011: A Remote Sensing Analysis of the
Tran Van Thoi District, Ca Mau Province, Vietnam. Remote Sensing, 7: 2899 - 2925.

Turan, S.O., Kadiogullari, A.I. and Gunlu, A. (2010). Spatial and temporal dynamics of land use pattern response to urbanization in Kastamonu. African Journal of Biotechnology, 9: 640 - 647.

Weng, Q.H. (2002). Land use change analysis in the Zhujiang Delta of China using satellite remote sensing, GIS and stochastic modelling. Journal of Environment Management, 64: 273 - 284.

Yang, H., Du, L., Guo, H. and Zhang, J. (2011). Tai'an land use Analysis and Prediction Based on RS and Markov Model. Procedia Earth and Planetary Science, 10: 2625 - 2630.

Zhang, R., Tang, C., Ma, S., Yuan, H., Gao, L. and Fan, W. (2011). Using Markov chains to analyze changes in wetland trends in arid Yinchuan Plain, China. Mathematical and Computer Modelling, 54: 924 - 930. 